\author{
ks. Wiestaw Hudek \\ Akademia Muzyczna im. Karola Szymanowskiego w Katowicach \\ https://orcid.org/0000-0002-1514-9161 \\ wieslaw.hudek@gmail.com
}

\title{
Ks. Robert Tyrata, Międzynarodowa Federacja Pueri Cantores w latach 1944-2017. Historia, ludzie, idee, Kraków 2019, 534 strony
}

\begin{abstract}
Przedstawiona historia Pueri Cantores za lata 1944-2017 jest opowieścią o ludziach i ich działaniu dla sprawy muzyki. Idee obecne w życiu Federacji, sięgające pierwszych lat XX wieku we Francji, ostatecznie znalazły swój rezonans w kolejnych 83 krajach świata. Są żywą historią Kościoła. Wychowanie młodych ludzi przez wartości chrześcijańskie, dbałość o jakość muzyki kościelnej, zwłaszcza tej liturgicznej, ale także głoszenie pokoju między ludźmi i w świecie na stale zagościły wszędzie tam, gdzie dotarła Federacja Pueri Cantores ${ }^{1}$.
\end{abstract}

Zacytowany fragment z recenzowanej rozprawy, wydobyty z jej „Zakończenia” stanowi swoistego rodzaju próbkę zarówno stylu, jak i zawartości monumentalnego (bo obejmującego 534 strony) opracowania pt. Międzynarodowa Federacja Pueri Cantores $w$ latach 1944-2017. Historia, ludzie, idee ks. prof. dr. hab. Roberta Tyrały, aktualnego rektora Uniwersytetu Papieskiego Jana Pawła II w Krakowie. Autor podjął się niezwykle cennego, a równocześnie trudnego zadania przedstawienia dziejów Międzynarodowej Federacji Pueri Cantores na podstawie zgromadzonych dokumentów źródłowych i dostępnej literatury. Jakkolwiek ze względu na pełnioną przez autora funkcję prezydenta Foederatio Internationalis Pueri Cantores (dalej: FIPC) można się domyślać, iż miał on swobodny dostęp do źródeł, szczególnie do watykańskiego archiwum FIPC, to z całą stanowczością trzeba stwierdzić, iż wykonał tytaniczną pracę, której efekty docenią nie tylko członkowie aktualnie zrzeszeni w federacjach narodowych, ale również przyszłe pokolenia.

1 R. Tyrała, Międzynarodowa Federacja Pueri Cantores w latach 1944-2017. Historia, ludzie, idee, Kraków 2019, s. 369. 
Rozprawa została podzielona na sześć rozdziałów, spiętych klamrami wstępu i zakończenia. Po zasadniczym korpusie pracy umieszczono omówienia zawartości publikacji w językach niemieckim i szwedzkim. Warto wspomnieć, iż były to języki, którymi posługiwano się w czasie podwójnej kadencji prezydentury ks. Tyrały (2009-2017) zarówno w korespondencji z chórami, jak i w informacjach zamieszczanych na stronie internetowej FIPC. Po wymienionych wyżej tekstach znalazły się: wykaz skrótów, bibliografia (obejmująca źródła, źródła drukowane oraz opracowania), a także cztery aneksy. Obejmują one: Federacje i Korespondentów Pueri Cantores na poszczególnych kontynentach, zarówno te, które dzisiaj są zrzeszone w FIPC, jak i te, które już dzisiaj nie działają; Spis kongresów organizowanych przez FIPC w latach 1947-2017; Zestawienie wybranego repertuaru wykonywanego podczas tychże kongresów, a także wiele cennych fotografii dokumentujących opisaną w publikacji historię FIPC.

Zapowiedziany w tytule trójpodział (historia - ludzie - idee) ma swoje odzwierciedlenie w podziale treści zawartych w poszczególnych rozdziałach. Rozdział I Powstanie i początki Federacji, obejmujący trzy paragrafy: Fundamenty, Status prawny oraz Watykan (zależność czy wspótpraca) przedstawia genezę powstania FIPC, a także jego status od początku istnienia organizacji aż po czasy współczesne. W kolejnym rozdziale zostały poruszone kwestie związane z funkcjonowaniem FIPC. Autor omawia formy zarządzania FIPC (Walne zgromadzenia i spotkania odpowiedzialnych), dalej miejsca z nią związane (Siedziba, sekretariat i archiwum), czasopismo „Pueri Cantores”, a także bardzo ważne kwestie finansowe.

Niezwykle intersujący dla czytelnika omawianej rozprawy może być rozdział trzeci omawiający działalność siedmiu prezydentów FIPC. Chronologicznie byli to: ks. Ferdynand Maillet (1944-1963), ks. Fiorenzo Romita (1963-1972), ks. Joseph Roucairol (1972-1984), Siegfried Koesler (1984-1992), Wim Buys (1992-2000), Josep Torrents (2000-2009) i ks. Robert Tyrała (2009-2017). Autor przedstawia swoich poprzedników jako wnoszących w życie federacji coś nowego, specyfikującego jej profil. Ksiądz Ferdynand Maillet, założyciel Federacji, został zaprezentowany jako wizjoner, który krzewił idę śpiewu dla pokoju i wartości chrześcijańskich i w ten sposób przez swój charyzmat przyczynił się do powstania FIPC. Jego następca ks. Fiorenzo Romita jako pracownik Stolicy Apostolskiej doprowadził do zatwierdzenia statutu Międzynarodowej Federacji Pueri Cantores. Do powrotu do pierwotnych źródeł fenomenu FIPC, tzn. kultywowania wartości chrześcijańskich, a także uprawiania muzyki na wysokim poziomie artystycznym, zachęcał kolejny prezydent organizacji ks. Joseph Roucairol. Pierwszy świecki prezydent FIPC, Siegfied Koesler, akcentował w swoim czasie kerygmatyczny walor muzyki, a także posługi zrzeszonych w FIPC chórów. Prezydent „przełomu” tysiącleci Wim Buys starał się z jednej strony o otwarcie FIPC na Europę Wschodnią (szczególnie 
zależało mu na Rosji), a z drugiej troszczył się o umocnienie federacji już istniejących. Josep M. Torrents dzięki swoim naturalnym zdolnościom rozszerzył rozumienie FIPC, nie tylko poprzez swoje kontakty z Watykanem, ale także poprzez otwartość na każdego przyczynił się do ugruntowania poczucia, iż FIPC to ,jedna wielka kochająca się rodzina”. Ostatnim z prezydentów objętych czasokresem założonym w dysertacji był jej autor, który poprzez podróże utrwalił dzieło swoich poprzedników, oraz doprowadził do tego, iż w momencie zakończenia jego drugiej kadencji FIPC skupiała ponad 40 tysięcy młodych śpiewaków połączonych tą samą wiarą i tymi samymi ideałami.

W IV rozdziale swojej monografii autor prezentuje sukcesywne rozszerzenie się idei Pueri Cantores na poszczególnych kontynentach. Ze względu na zasięg działania FIPC najwięcej miejsca poświęca krajom europejskim, a następnie omawia federacje działające na kontynentach: Ameryki Północnej, Środkowej i Południowej, Afryki, Azji, wreszcie Australii i Oceanii. Kwestie poruszone w niniejszym rozdziale zostały przedstawione w formie tabel (s. 479-485). Niezwykle ciekawy materiał źródłowy zawiera część pracy poświęcona kongresom międzynarodowym. Treść metodologicznie została podzielona na dwa okresy, dla których cezurą stał się Sobór Watykański II, nie tylko jako niezwykle ważne wydarzenie w historii Kościoła, ale również istotny punkt odniesienia w pojmowaniu znaczenia muzyki liturgicznej. Kongresów do Vaticanum II odbyło się 10, a po nim 31; 35 odbyło się w krajach europejskich, zaś 6 na innych poza Europą (Meksyk 1969/1970; Japonia 1977; Wenezuela 1979/1980; Kanada 1995; USA 2013; Brazylia 2017). Najwięcej kongresów FIPC, bo aż 14 odbyło się w Rzymie (1949; 1951; 1954; 1960/1961; 1964; 1967; 1974/1975; 1980/1981; 19871988; 1993/1994; 1999/2000; 2005/2006; 2010/2011; 2015/2016), zaś w Paryżu odbyły się 4 (1947; 1956; 1985; 2014). Zestawienie wszystkich 41 kongresów przedstawia aneks (ss. 486-487). W ostatnim rozdziale autor prezentuje instytucje, z którymi FIPC współpracuje. Wśród szczegółowo omówionych w monografii osobne paragrafy zostały poświęcone następującym podmiotom: Rassegna Internazionale di Musica Sacra, Loreto; Festival Europeo Cori Giovanili; Festival Zelioli, Lecco; Royal School of Church Music, Salisbury, a także Pontificio Instituto di Musica Sacra, Roma. W dalszej części omówiono współpracę FIPC z innymi instytucjami, m.in. z Parlamentem Europejskim w ramach działania w Europa Cantat, czyli Festiwalu Śpiewającej Europy.

Autor pracy, co godne zauważenia, wielokrotnie podkreśla, iż opisywane wydarzenia, przedstawione idee oraz efekty pracy poszczególnych prezydentów i zarządów FIPC to niezwykła historia ludzi, młodych śpiewaków, w sumie w 84 federacjach/ krajach, w których działają, działały chóry lub podejmowano starania o powołanie do życia federacji krajowych. Za tymi liczbami kryją się konkretne 
zespoły, ich dyrygenci, akompaniatorzy, asystenci kościelni, ale przede wszystkim sami chórzyści i ich rodziny. Bez wątpienia fenomen opisany przez ks. Roberta Tyrałę to niezwykły dar, jaki Kościół otrzymał i który - jeśli tylko będzie kontynuowany i pielęgnowany - będzie przynosił konkretne owoce.

Autor, o czym była już mowa, wykorzystał w swojej pracy gigantyczny aparat dostępnych źródeł, które „zajmują” 53 strony monografii, co stanowi 10\% objętości całego opracowania. Warto dodać, iż autor z benedyktyńską precyzją digitalizował dokumenty zgromadzone $\mathrm{w}$ archiwum FIPC w Watykanie, w efekcie wykonując ponad 45 tysięcy skanów. W trakcie swojej prezydentury odbył 183 podróże, docierając do wszystkich istniejących federacji. Już te dwa fakty budzą respekt i są wystarczającym dowodem, iż w prezentowanej pracy mamy do czynienia z niezwykle rzetelną narracją, opartą na solidnej bazie źródłowej.

Biorąc do ręki dysertację ks. Tyrały, możemy mieć pewność, iż obcujemy z dziełem pomnikowym, do którego będą sięgać kolejni badacze oraz kontynuatorzy analitycznych spekulacji dotyczących przeszłości, teraźniejszości oraz perspektyw działania FIPC. Daje ona możliwości prowadzenia dalszych badań, w różnych obszarach, zarówno historycznym, geograficznym, muzykologiczno-liturgicznym, jak i teologicznym. Wymienione propozycje nie wyczerpują kierunków dalszej penetracji tej niezwykle interesującej problematyki. Na koniec warto dodać, iż dodatkową wartością dzieła jest jego ascetyczna, ale pełna szlachetnej prostoty grafika, w której posłużono się m.in. logo kongresu rzymskiego (2010/2011), przedstawiającym kopułę Bazyliki św. Piotra w Rzymie, a na jej podstawie umieszczono gregoriański zapis wielkanocnego alleluja oraz tarczę FIPC. Jest to zatem dyskretny zabieg przypominający od pierwszej strony okładki, poprzez strony tytułowe poszczególnych rozdziałów, o niezapomnianych słowach św. Pawła VI skierowanych do chórzystów FIPC: „Wy jesteście w Kościele tym, czym Alleluja w liturgii: ciągle nową radością...”. Z całą pewnością lektura monografii FIPC autorstwa ks. prof. dr. hab. Roberta Tyrały wielu czytelnikom sprawi prawdziwą intelektualną przyjemność, a także da sporą porcję radości. 